\title{
ĐÁNH GIÁ KỄT QUẢ PHẪU THUẬT PHỤC HỒI LỦU THÔNG ĐộNG MẠCH CHI DƯớI
}

Đỗ Kim Qué̂*, Nguyễn Anh Trung*

\section{TÓM TẮT}

Trong thời gian 1 năm từ $1 / 2015-1 / 2016$ có 62 trường hợp tắc động mạch chi dướiđược điều trị phục hồi lưu thông động mạch tại Bệnh viện Thống Nhất và bệnh viện Đại học Y Dược TP Hồ Chí Minh. Tuổi trung bình là 68,65 nhỏ nhất là 23 và lớn nhất là 95 tuổi. Có 46 nam và 16 nữ. 9 trường hợp tắc động mạch chủ bung. 33 trưởng hợp tắc động mạch chậu, 38 trường hợp tắc động mạch đùi khoeo, 40 trường hợp tắc động mạch chày. 46 trường hợp vào viện với tổn thương loét hoặc hoại tủ ở chân. Phẫu thuật cầu nối động mạch chủ - động mạch đùi 2 bên được áp dụng cho6 trường hợp, cầu nối động mạch chủ bụng động mạch chậu 2 bên cho 6 trường hợp.Cầu nối động mạch chậu - đùi trong 15 trường hợp, Cầu nối động mạch đùi - đùi (chéo bên) cho 4 trường hợp. 11 trường hợp được thực hiện phẫu thuật cầu nối động mạch đùi - khoeo, 10 trường hợp thực hiện cầu nồi động mạch đùi chày. 10 trường hợp được can thiệp nội mạch nong và/hoặc đặt stent động mạch. Kết quả điều trị sớm: không có tử vong sau mổ, 3 trưòng hợp phải đoạn chi, 2 trường hợp $(2,7 \%)$ bị tắc động mạch sau phục hồi lưu thông. 4 bệnh nhân $(5,4 \%)$ có hẹp động mạch có ý nghĩa $(>80 \%)$ sau phục hồi lưu thông. 44 trường hợp $(59,5 \%)$ có $\mathrm{ABI}>0,9$ sau phẫu thuật.

Tù khóa: Tắc động mạch, động mạch chủ chậu, cầu nối động mạch. Cầu nối động mạch ngoài giải phẫu.

\section{MID TERM RESULTS OF REVASCULARIZATION FOR LOWER LIMB ARTERIAL OCCLUSION}

There are 62 patients who underwent revascuaization for chronic arterial occlusion of lower limb in Thong nhat hospitaland Medical University hospital during 1 years from 1/2015 to 1/2016. Mean age is 68.65 ( range $23-85$ ). Thirtynine of them are male. 2 cases have juxtarenal aortic occlusion and 8 patients have infrarenal aortic occlusion. Arterosclerosis affect in 42 cases. Eighteen of them admitted with necrosis of their foot. Thoracic aorto bifemoral bypass operation is carried out in 2 cases, Abdominal aorto - bi femoral bypass in 5 and abdominal - biiliac bypass in 2 patients 10 cases underwent PTA and/or stenting. 15 cases underwent ilio femoral bypass. Extraanatomic bypass was performed in 12 cases.

No mortality, amputation in 3 cases $(4,8 \%)$. 2 cases $(3,2 \%)$ had arterial occlusion after revascularization, 4 cases $(6,4 \%)$ had restenosis > 80\%. 44 limbs had ABI $>0,9$ after revascularization.

Key words: Arterial occlusion. Aortoiliac artery, Arterial bypass, extraanatomic arterial bypass.

* Bệnh viện Thống nhất Thành phố HCM Người chịu trách nhiệm khoa hoc: PGS.TS. Đố Kim Quế Ngày nhận bài: 15/10/2016 - Ngày Cho Phép Đăng: 05/11/2016 Phản Biện Khoa học: PGS.TS. Đặng Ngọc Hùng

GS.TS. Lê Ngoc Thành 


\section{MỞ ĐÀ̀U}

Bệnh động mạch chi dưới mạn tính là một bệnh lý thường gặp đặc biệt ở những bệnh nhân lớn tuổi, có yếu tố nguy cơ tim mạch. Theo thống kê khoảng 3-10\% dân số dưới 70 tuổi có bệnh động mạch chi dưới, và tỉ lệ này ở bệnh nhân trên 70 tuổi là 10-20\%.Nếu không được điều trị thích hợp bệnh nhân sẽ bị hoại tử chi do thiếu máu nuôi. Hiện nay phần lớn các trường hợp bệnh được phát hiện ở giai đoạn muộn đã có biến chứng.

Nghiên cứu tầm soát phát hiện bệnh ở giai đoạn sớm có ý nghĩa hết sức quan trọng trong việc làm giảm nguy cơ phẫu thuật cắt cụt chi do thiếu máu nuôi.Với sự trang bị các thiết bị chẩn đoán sớm như máy đo chỉ số cổ chân cánh tay $(\mathrm{ABI})$, Duplex mạch máu, chụp cắt lớp điện toán động mạch, chụp cộng hưởng từ mạch máu và $X$ quang số hóa xóa nền giúp các thầy thuộc chẩn đoán chính xác bệnh ngay ở giai đoạn sớm. [8,12]

Các phương pháp điều trị can thiệp nội mạch và phẫu thuật hiện nay đã làm thay đổi tiên lượng của người bệnh động mạch chi dưới. [14, 16]

Các nghiên cứu về bệnh động mạch chi dưới được thực hiện khá nhiều tại các bệnh viện trong nước, tuy nhiên những nghiên cứu toàn diện về vấn đề này chưa nhiều, đặc biệt là các nghiên cứu đánh giá khách quan và dài hạn về kết quả điều trị bệnh lý này.

Nguyễn Hoàng Bình và cộng sự $[1,2]$ báo cáo kết quả điều trị tắc động mạch chủ chậu tại bệnh viện Chợ rẫy trong thời gian 8 năm từ 1996 - 2004 có 56 trường hợp tắc động mạch chủ bụng, tỉ lệ cắt cụt chi là $13 \%$.

Đỗ Kim Quế và CS [6] báo cáo kết quả điều trị tắc động mạch chủ chậu mạn tính Trong thời gian 10 năm từ $1 / 2004-1 / 2014$ với 46 trường hợp tắc động mạch chủ chậu được điều trị tại Bệnh viện Thống nhất. Tuổi trung bình là 65,7 nhỏ nhất là 32 và lớn nhất là 81 tuổi. Có 39 nam và 7 nữ. 7 trường hợp tắc động mạch chủ bung dưới động mạch thận và 2 trường hợp tắc ngang động mạch thận. 37 trường hợp tắc động mạch chậu. 42 trường hợp tắc do xơ vữa động mạch, 4 trường hợp có nguyên nhân do viêm xơ hóa động mạch chủ. 18 trường hợp vào viện với tổn thương loét hoặc hoại tủ ở chân. Phẫu thuật cầu nối động mạch chủ ngực - động mạch đùi 2 bên được áp dụng cho 2 trường hợp, cầu nối động mạch chủ bụng động mạch chậu 2 bên cho 2 trường hợp, động mạch chủ bụng động mạch đùi 2 bên cho 5 trường hợp. Cầu nối động mạch nách - đùi trong 8 trường hợp, Cầu nối động mạch đùi - đùi (chéo bên) cho 4 trường hợp. 15 trường hợp được thực hiện phẫu thuật cầu nối động mạch chậu - đùi. 10 trường hợp được can thiệp nội mạch nong và/hoặc đặt stent động mạch. Kết quả điều trị sớm: 1 trường hợp tử vong do nhồi máu cơ tim sau mổ, 3 trường hợp phải đoạn chi, các trường hợp còn lại đạt kết quả tốt.

Theo nghiên cứu dịch tễ bệnh động mạch ngoại biên của Criqui $\mathrm{MH}$ và nghiên cứu về đau cách hồi của Murabito JM cho thấy xơ vữa động mạch là nguyên nhân chính gây tắc động mạch chi dưới.

Những nghiên cứu gần đây của Hooi JD, Criqui $\mathrm{MH}$, Simons $\mathrm{PD}$, và House $\mathrm{AK}$ cho thấy, tần suất bệnh động mạch chi dưới tăng cao hơn ở bệnh nhân có tiểu đường, rối loạn mỡ máu, hút thuốc lá, tăng huyết áp, có hẹp động mạch cảnh, nhồi máu cơ tim. Các nhóm nguy cơ cao có bệnh động mạch chi dưới cần tầm soát bao gồm:

- Người dưới 50 tuổi có tiểu đường và 1 yếu tố nguy cơ xơ vữa động mạch (hút thuốc lá, tăng huyết áp, tăng cholesterol, tăng homocystein)

- Người 50 - 69 tuổi có tiểu đường hoặc hút thuốc.

- Người trên 70 tuổi. 
- Người có đau chân khi gắng sức hoặc lúc nghỉ,

- Khám mạch chi dưới có dấu hiệu bất thường.

- Người có bệnh xơ vữa động mạch cảnh, động mạch vành, động mạch thận.

Phẫu thuật cầu nối động mạch vẫn là phương pháp điều trị chính cho những trường hợp hẹp / tắc động mạch chủ với kết quả dài hạn rất tốt. Nong và đặt stent động mạch đã được áp dung trong điều trị hẹp động mạch chi dưới đơn giản với kết quả khả quan.

Nhằm đánh giá hiệu quả của phẫu thuật phục hồi lưu thông động mạch cho bệnh nhân tắc động mạch chi dưới mạn tính chúng tôi tiến hành nghiên cứu này với các mục tiêu:

Đánh giá tỉ lệ đoạn chi sau phẫu thuật phục hồi lưu thông động mạch.

Đánh giá tỉ lệ hẹp và tắc động mạch sau phục hồi lưu thông động mạch.

Đánh giá sự cải thiện của $\mathrm{ABI}$ sau phục hồi lưu thông động mạch.

\section{II. ĐỐI TƯợNG VÀ PHƯƠNG PHÁP} NGHIÊN CÚU

2.1. Đối tượng nghiên cứu: Toàn bộ bênh nhân bị tắc động mạch chidướimạn tính được điều trị phục hồi lưu thông động mạch tại bệnh viện Thống Nhất và bệnh viện Đại học Y Dược TP Hồ Chí Minh trong thời gian 1 năm từ tháng 01/2015 tới tháng 01 năm 2016.

\subsection{Phương pháp nghiên cứu:}

Chúng tôi thực hiện nghiên cứu tiền cứu mô tả hàng loạt ca.

Về chẩn đoán chúng tôi lưu ý tới triệu chứng khởi phát, thời gian bệnh, tần suất các triệu chứng thiếu máu nuôi mạn tính, đánh giá giai đoạn thiếu máu nuôi chi, chỉ số huyết áp cổ chân - cánh tay (ABI).

Chúng tôi xác định vị trí động mạch tắc dựa trên siêu âm Doppler mạch máu màu và/ hoặc chụp cắt lớp điện toán động mạch, chụp động mạch cản quang số hoá.

Về điều trị: phẫu thuật cầu nối chủ bụng chậu hoặc đùi 2 bên được chỉ định cho các trường hợp hẹp động mạch chủ bụng dưới động mạch thận $>1 \mathrm{~cm}$, các trường hợp hẹp sát động mạch thận chúng tôi chỉ định phẫu thuật cầu nối chủ ngực đùi 2 bên. Cầu nối chủ hoặc chậu - đùi cho bệnh nhân hẹp 1 bên động mạch đùi. Cầu nối động mạch nách đùi 2 bên hoặc cầu nối chéo đùi đùi được chỉ định cho những trường hợp có thể trạng kém.Cầu nối động mạch đùi khoeo hoặc đùi chày sau cho nhưng bệnh nhân hẹp động mạch đùi nông, động mạch khoeo. Nong và đặt stent động mạch cho bệnh nhân hẹp động mạch chủ chậu TASC A hoặc B.

Đánh giá kết quả sớm sau mổ: tỉ lệ tử vong, tỉ lệ cắt cụt chi.

Các biến chứng trong và sau mổ.

Đánh giá tỉ lệ tắc, hẹp cầu nối/stent động mạch.

Đánh giá sự cải thiện tình trạng thiếu máu nuôi chi, sự cải thiện của $\mathrm{ABI}$.

\section{KẾT QUẢ:}

\subsection{Tuổi và giới tính:}

Trong thời gian 1 năm từ 2015 - 2016 chúng tôi đã điều trị cho 62 bệnh nhân bị TĐMCDMT trong đó có 46 bệnh nhân namchiếm tỉ lệ 74,2\% và 16 bệnh nhân nữ chiếm tỉ lệ 25,8\%.

Tuổi trung bình là 68,65 , trẻ nhất là 23 tuổi và lớn tuổi nhất là 95 . Đa số bệnh nhân lớn tuổi, 33 trường hợp $(53,2 \%)$ trên 70 tuổi.

\subsection{Những đặc điểm lâm sàng.}

Đặc điểm khoảng cách đi bộ trước mổ. 
Bảng 1. Đặc điểm khoảng cách đi bộ trước mổ.

\begin{tabular}{|c|c|c|c|}
\hline Nhóm bệnh & n & $\overline{\mathrm{X}} \pm$ SD (mét) & \\
\hline Nam & 46 & $80,8 \pm 38,9$ & \multirow{2}{*}{$\mathrm{P}>0.05$} \\
\hline Nữ & 16 & $79,3 \pm 39,1$ & \\
\hline Chung & 62 & $80,4 \pm 39,3$ & \\
\hline
\end{tabular}

- 61 bệnh nhân có triệu chứng đau, trong đó 41 bênh nhân có đau lúc nghỉ, 20 bênh nhân có triệu chúng đau cách hồi.

- Khoảng cách đi bộ trung bình 80,4 \pm 39,3 (mét) dài nhất là 170 mét, ngắn nhất là 10 mét.

Đặc điểm hoại tử chi và đau cách hồi trước mổ.

Trong tổng số 62 bệnh nhân nghiên cứu:

- Có 16 bệnh nhân không hoại tử chi chiếm tỉ lệ 25,8\%, 46 bệnh nhân có hoại tử chi ở 1 hoặc 2 bên chân chiếm tỉ lệ 74,2\%.

- Có 32 bệnh nhân đau khi nghỉ ngơi chiếm tỉ lệ 51,6\%.

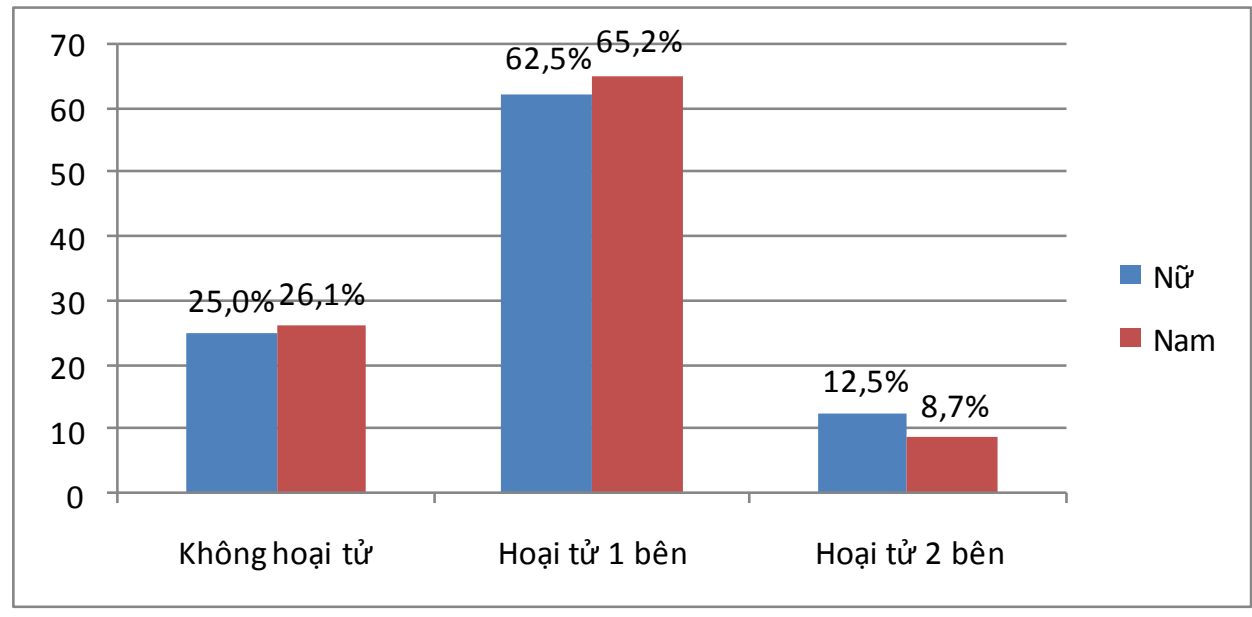

Biểu đồ 1. Đặc điểm tỉ lệ\% hoại tử chi trước mổ

\section{3. Đặc điểm ABI trước mổ.}

Bảng 2. Giá trị ABI trung bình trước mổ.

Nghiên cứu ABI ở 62 bệnh nhân với 74 chi bị thiếu máu nuôi cho thấy:

\begin{tabular}{|c|c|c|}
\hline ABI & $\mathbf{n}$ & Tỉ lệ (\%) \\
\hline$<0,4$ & 42 & 56,8 \\
\hline $0,4-0,79$ & 29 & 39,2 \\
\hline $0,8-0.90$ & 03 & 4,0 \\
\hline Tồng số & 74 & 100,0 \\
\hline
\end{tabular}

- Giá trị $\mathrm{ABI}$ trung bình chung của nhóm $\mathrm{BN}$ nghiên cứu $0,35 \pm 0,14$ là cao nhất là 0,85 và thấp nhất là 0 . Đa số các trường hợp $\mathrm{ABI}<0,4$ chiếm $56,8 \%$. 


\section{4. Đặc điểm thương tổn trên siêu âm Doppler:}

Bảng 3. Đặc điểm mức độ hẹp trên siêu âm trước mổ.

\begin{tabular}{|c|c|c|}
\hline Mức độ hẹp & Số trường hợp & Tỉ lệ (\%) \\
\hline$<50 \%$ & 0 & 0 \\
\hline $50-80 \%$ & 5 & 6,8 \\
\hline $80-99 \%$ & 28 & 37,8 \\
\hline $100 \%$ & 41 & 55,4 \\
\hline Tổng số & $\mathbf{7 4}$ & $\mathbf{1 0 0 , 0}$ \\
\hline
\end{tabular}

- 100\% các trường hợp nghiên cứu có mức hẹp $>50 \%$.

- 41 trường hợp tắc hẹp hoàn toàn không khảo sát được dòng chảy, chiếm 55,4\%.

3.5. Những đặc điểm thương tổn động mạch trên chụp điện toán cắt lớp mạch máu:

Bảng 4. Phân loại số tầng động mạch thương tổn

\begin{tabular}{|l|c|c|}
\hline \multicolumn{1}{|c|}{ Vị trí thương tổn } & Có thương tổn & Tỉ lệ (\%) \\
\hline Động mạch chủ - chậu & 38 & 28,2 \\
\hline Động mạch đùi khoeo & 52 & 38,5 \\
\hline Động mạch chày & 45 & 33,3 \\
\hline Tổng số & $\mathbf{1 3 5}$ & $\mathbf{1 0 0 , 0}$ \\
\hline
\end{tabular}

- Thương tổn động mạch có xu hướng gặp nhiều hơn ở những vị trí động mạch xa gốc chi.

Bảng 5. Phân loại số tầng động mạch thương tổn.

\begin{tabular}{|c|c|c|}
\hline Số tầng thương tổn & $\mathbf{n}$ & Tỉ lệ (\%) \\
\hline 1 tầng & 10 & 16,1 \\
\hline 2 tầng & 31 & 50,0 \\
\hline 3 tầng & 21 & 33,9 \\
\hline Tổng số & 62 & 100,0 \\
\hline
\end{tabular}

- Gặp nhiều nhât là thương tổn động mạch 2 tầng chiếm $50,0 \%$, kết đến là tổn thương ở 3 tầng $33,9 \%$. 


\subsection{Phương pháp phẫu thuật:}

Bảng 6. Phương pháp điều trị:

\begin{tabular}{|l|c|c|}
\hline Loại cầu nối & Số trường hợp & Tỷ lệ (\%) \\
\hline Cầu nối chủ - chậu & 6 & 9,7 \\
\hline Cầu nối chủ - đùi & 6 & 9,7 \\
\hline Cầu nối chậu - đùi & 15 & 24,2 \\
\hline Cầu nối đùi - đùi & 4 & 6,5 \\
\hline Cầu nối đùi - khoeo & 11 & 17,7 \\
\hline Cầu nối đùi - chày & 10 & 16,1 \\
\hline Can thiệp nội mạch & 10 & 16,1 \\
\hline
\end{tabular}

- Cao nhất là loại cầu nối động mạch chậu- đùi 24,2\%, tiếp đến là cầu nối động mạch đùi khoeo $17,7 \%$.

\subsection{Kết quả phẫu thuật:}

Biến chứng sau mổ.

Bảng 7. Các biến chứng sau mổ.

\begin{tabular}{|l|c|c|}
\hline \multicolumn{1}{|c|}{ Biến chứng } & Số trường họ̣p & Tỷ lệ (\%) \\
\hline Chảy máu & 2 & 3,2 \\
\hline Tụ máu vùng mố & 5 & 8,1 \\
\hline Tắc động mạch & 2 & 3,2 \\
\hline Tổng & 9 & 14,5 \\
\hline
\end{tabular}

- Trong 62 trường hợp phẫu thuật cầu nối và can thiệp nội mạch có 9 trường hợp có biến chứng sau mổ chiếm $14,5 \%$.

- 3 trường hợp phải cắt cụt chi.

Tắc/hẹp lòng mạch sau mổ.

Bảng 8. Đặc điểm mức độ hẹp lòng mạch trên siêu âm sau mổ.

\begin{tabular}{|c|c|c|}
\hline Mức độ hẹp & Trước mổ & Sau mổ \\
\hline$<50 \%$ & 0 & $59(79,7 \%)$ \\
\hline $50-80 \%$ & $5(6,8 \%)$ & $9(12,2 \%)$ \\
\hline $80-99 \%$ & $28(37,8 \%)$ & $4(5,4 \%)$ \\
\hline $100 \%$ & $41(55,4 \%)$ & $2(2,7 \%)$ \\
\hline Tổng số & $\mathbf{7 4}(\mathbf{1 0 0 \%})$ & $\mathbf{7 4}(\mathbf{1 0 0} \%)$ \\
\hline
\end{tabular}


59 trường hợp sau mổ không còn hẹp động mạch có ý nghĩa chiếm 79,7\%,2 trường hợp tắc cầu nối động mạch sau mổ chiếm $2,7 \%$. Sự thay đổi mức hẹp trước và sau mổ có ý nghĩa thống kê $\mathrm{P}<0,01$.

\section{8. Đặc điểm ABI sau mổ.}

Bảng 9. Giá trị ABI sau mổ.

\begin{tabular}{|c|c|c|}
\hline ABI & Trước mổ & Sau mổ \\
\hline$<0,4$ & $42(56,8 \%)$ & $2(2,7 \%)$ \\
\hline $0,4-0,79$ & $29(39,2 \%)$ & $10(13,5 \%)$ \\
\hline $0,8-0.90$ & $3(4,0 \%)$ & $18(24,3 \%)$ \\
\hline$>0,9$ & 0 & $44(59.5 \%)$ \\
\hline Tổng số & $\mathbf{7 4}(\mathbf{1 0 0} \%)$ & $\mathbf{7 4} \mathbf{1 0 0 \%})$ \\
\hline
\end{tabular}

- ABI trung bình sau mổ là $0,764 \pm 0,14$.

- Có 2 trường hợp ABI sau mổ không thay đổi so với trước mổ, chiếm tỉ lệ 2,7\%.

- Có 72 trường hợp ABI sau mổ cải thiện hơn trước mổ chiếm 97,3\%.

- Sự khác biệt $\mathrm{ABI}$ trước và sau mổ có ý nghĩa thống kê với $\mathrm{P}<0,01$.

3.9. Đặc điểm khoảng cách đi bộ sau mổ 1 tháng và 6 tháng.

Đặc điểm mức độ đau cách hồi sau mổ.

Bảng 8. Đặc điểm mức độ đau cách hồi sau mổ.

\begin{tabular}{|l|c|c|c|}
\hline Triệu chứng đau & Trước mổ & Sau mổ 1 tháng & Sau mổ 6 tháng \\
\hline Không triệu chứng & $1(1,6 \%)$ & $50(80,6 \%)$ & $55(90,2 \%)$ \\
\hline Đau cách hồi & $20(32,3 \%)$ & $8(12,9 \%)$ & $6(9,8 \%)$ \\
\hline Đau khi nghỉ & $41(66,1 \%)$ & $4(6,5 \%)$ & 0 \\
\hline
\end{tabular}

- Sau mổ 1 tháng 58 trường hợp có cải thiện rõ rệt chiếm 93,5\%, hết đau sau mổ 50 trường hợp chiếm $80,6 \% .4$ trường hợp không thay đổi, chiếm $6,5 \%$. $(\mathrm{P}<0,01)$

- Sau mổ 6 tháng 61 bệnh nhân được theo dõi còn $9,8 \%$ có đau cách hồi.

Bảng 9. Những thay đổi khoảng cách đi bộ sau mổ 1 tháng và 6 tháng.

\begin{tabular}{|c|c|c|c|}
\hline Nhóm bệnh & Sau mổ1 tháng (mét) & sau mổ 6 tháng (mét) & P \\
\hline Nam & $95,4 \pm 24,6$ & $202,4 \pm 26,7$ & \multirow{2}{*}{ ( 10,01} \\
\cline { 1 - 3 } Nữ & $109,6 \pm 15,0$ & $212,8 \pm 90,4$ & \\
\cline { 1 - 3 } Chung & $99,1 \pm 23,2$ & $205 \pm 23,7$ & \\
\hline
\end{tabular}


Theo dõi sau mổ 1 tháng và 6 tháng chúng tôi ghi nhận:

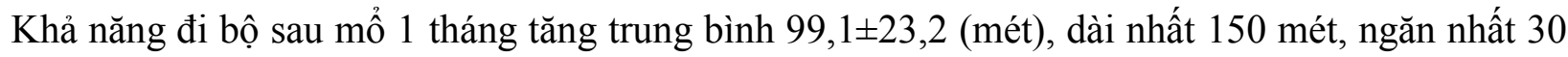
mét; sự khác biệt có ý nghĩa thống kê với $\mathrm{P}<0,01$.

Khả năng đi bộ sau mổ 6 tháng tăng so với khi xuất viên trung bình 205 $\pm 23,7$ (mét), dài nhất 265 mét, ngăn nhất 103 mét; sự khác biệt có ý nghĩa thống kê với $\mathrm{P}<0,01$.

3.10. Kết quả siêu âm Doppler động mạch và chụp điện toán cắt lớp mạch máu sau mổ 6 tháng:

Theo dõi tới 6 tháng có 52 bênh nhân được làm siêu âm Doppler và 26 bệnh nhân được chụp điện toán cắt lớp mạch máu với kết quả như sau:

Bảng 10. Đặc điểm mức độ hẹp lòng mạch trên siêu âm và chụp điện toán cắt lớp mạch máu

\begin{tabular}{|c|c|c|}
\hline Mức độ hẹp & Siêu âm Doppler & CTA \\
\hline$<50 \%$ & $41(78.9 \%)$ & $14(53,8 \%)$ \\
\hline $50-80 \%$ & $5(9,6 \%)$ & $6(23,1 \%)$ \\
\hline $80-99 \%$ & $2(3,8 \%)$ & $2(7,7 \%)$ \\
\hline $100 \%$ & $4(7,7 \%)$ & $4(15,4 \%)$ \\
\hline Tổng số & $52(100 \%)$ & $26(100 \%)$ \\
\hline
\end{tabular}

\section{BÀN LUẬA}

Mặc dù TĐMCDMT là bệnh lý thường gặp, đa số tới điều trị ở giai đoạn muộn có đau lúc nghỉ và hoại tử chi gây ảnh hưởng lớn đến chất lượng cuộc sống của bệnh nhân.

Tắc động mạch chi dưới thường gặp ở nam giới và nguyên nhân chính là do xơ vữa động mạch. Trong nghiên cứu của chúng tôi $74,2 \%$ là nam giới.

Phần lớn các trường hợp có tổn thương nhiều nơi, và động mạch chậu đùi là vị trí thường bị tổn thương nhất.[3,4,7]

Tắc đông mạch chủ bụng là tổn thương ít gặp nhưng điều trị phẫu thuật phức tạp. đa số các trường hợp tắc động mạch chủ bụng có tổn thương động mạch chậu đùi với nhiều mức độ khác nhau, đa số các tác giả chia hẹp động mạch chủ thành 3 type: $[10,12]$
Type I tổn thương khu trú tại động mạch chủ bụng và động mạch chậu chung,

Type II tổn thương lan rộng tới động mạch chậu ngoài, nhưng không có tổn thương động mạch đùi.

Type III tổn thương toàn bộ hệ động mạch chi dưới.

Trong nghiên cứu của chúng tôi có tới 7 trường hợp thuộc type III, kết quả này cũng tương tự như các nghiên cứu khác như Brewter, Darling, Nguyễn Hoàng Bình, Trần Quyết Tiến. $[1,2,3,6,9]$

Tất cả bệnh nhân của chúng tôi đều nhập viên khi đã có triệu chứng lâm sàng, trong đó tới $74,2 \%$ các trường hợp đã có dấu hiệu hoại tử đầu chi. Theo Brewter và Darling [10] 90\% các trường hợp bệnh lý tắc động mạch chủ chậu có triệu chứng lâm sàng khi vào viện.

Chẩn đoán tắc động mạch chi dưới thường không khó ở giai đoạn muộn, tuy nhiên ở giai 
đoạn sớm cần các phương tiện hỗ trợ. $\mathrm{ABI}$ là chỉ số rất có giá trị trong tầm soát hẹp động mạch chi dưới ở giai đoạn sớm và đặc biệt để đánh giá hiệu quả điều trị.

Để đánh giá chính xác thương tổn và chọn lựa phương pháp phẫu thuật thích hợp cần chụp động mạch cản quang. Trong $1-2$ thập niên gần đây các phương pháp chẩn đoán ít xâm lấn đã được sử dụng rộng rãi và cho thấy độ nhậy cảm và độ chuyên biệt cao trong chẩn đoán thương tổn động mạch chủ bụng.

Chúng tôi nhận thấy, siêu âm Duplex và chụp cắt lớpđiện toán động mạch có kết quả chính xác phù hợp với chụp động mạch cản quang trong đasố các trường hợp trong nghiên cứu này.

Về điều trị, cho tới nay phẫu thuật vẫn giữ một vị trí quan trọng, mặc dù các thủ thuật can thiệp nội mạch đã được áp dụng một cách rộng rãi. Theo Rholl và Breda [23]khả năng can thiệp nội mạch thành công cho hẹp động mạch chủ lên tới $95 \%$, và $20 \%$ bị hẹp tái phát sau 5 năm. Tuy nhiên phương pháp nong và đặt stent động mạc chỉ có thể áp dụng cho những trường hợp hẹp động mạchđơn giản thuộc nhóm TASK $\mathrm{A}$ và $\mathrm{B}$, trong nghiên cứu của chúng tôi có 10 trường hợp được chỉ định cho can thiệp nội mạch. $[14,16]$

Tùy thuộc vị trí động mạch chủ tắc và thể trạng của bệnh nhân mà chúng ta chọn lựa phương pháp phẫu thuật thích hợp. Phẫu thuật cầu nối động mạch nách đùi là phương pháp được chọn cho những trường hợp thể trạng bệnh nhân kém có nguy cơ cao.[20, 22, 26, 28]

Phẫu thuật cầu nối động mạch chủ ngực - 2 động mạch đùi là phương pháp an toàn và hiệu quả cho những trường hợp tắc động mạch chủ cao ngang động mạch thận. [9, 20,24]
Những trường hợp tắc động mạch chủ dưới động mạch thận nên được làm cầu nối động mạch chủ chậu hoặc chủ đùi 2 bên. [13, $15,18,19,22,25]$.

Phẫu thuật cầu nối động mạch chậu - đùi, đùi - khoeo, đùi chày - sau là phương pháp phục hồi lưu thông động mạch cho kết quả tốt nhất.

Kết quả điều trị của chúng tôi rất khả quan, trong 62 bệnh nhân được nghiên cứu không có tử vong. Tỉ lệ cắt cụt chi thấp $3,8 \%$. Các báo cáo cho thấy phẫu thuật cho tỉ lệ thành công cao $98 \%$ - 100\% và tỉ lệ hẹp tái phát thấp $5-10 \%$ sau 5 năm.

Trong nghiên cứu của chúng tôi, $\mathrm{ABI}$ cải thiện sau phẫu thuật trong 97,3\%, trong đó59,5\% các trường hợp có $\mathrm{ABI}$ bình thường $(>0,9)$.

Khoảng cách đi bộ của bệnh nhân cũng được cải thiện rõ rệt sau phẫu thuật phục hồi lưu thông động mạch. $90 \%$ các trường hợp không còn đau chi sau 6 tháng.

Tỉ lệ hẹp động mạch $>80 \%$ sau 6 tháng trong nghiên cứu của chúng tôi là $11,5 \%$, đây là kết quả khá tốt so với trong y văn.

\section{KẾT LUẬN}

TĐMCDMT vẫn còn là một bệnh lý khó xử trí, tî̉ lệ bệnh nhân vào viện muộn với chi hoại tử còn cao. Cần đánh giá kỹ vị trí và tình trạng mạch máu ngoại biên trước khi chọn lựa phương pháp điều trị cho bệnh nhân.

Duplex và chụp cắt lớp điện toán động mạch là phương pháp có độ nhậy và độ chuyên cao trong chẩn đoán tắc động mạch chi dưới mạn tính.

Phẫu thuật cầu nối động mạch và đặt stent động mạch cho kết quả điều trị tốt cho bệnh nhân. Tỉ lệ cắt cụt chi là $4,8 \%$, tỉ lệ hết đau và cải thiện $\mathrm{ABI}$ đạt trên $90 \%$. 


\section{TÀI LIỆU THAM KHẢO}

1. Nguyễn Hoàng Bình, Trần Quyết Tiến. (2005) Điều trị ngoại khoa tắc động mạch chủ bụng - động mạch chậu mạn tính. Y học TP. Hồ Chí Minh. 9 (phụ bản 1): 74 - 82.

2. Nguyễn Hoàng Bình, Trần Quyết Tiến, Đỗ Kim Quế (2006) Điều trị ngoại khoa tắc động mạch chủ chậu mạn tính. Y học Việt nam. 328: 153- 160 .

3. Nguyễn Đình Long Hải (2012) Đánh Giá Kết Quả Phẫu Thuật Cầu Nối Động Mạch Chủ Bụng- Đùi Hai Bên, Y học TP. Hồ Chí Minh. 60: 53-58.

4. Đỗ Kim Quế (2005) Tắc động mạch chủ bụng mạn tính: Chẩn đoán và điều trị ngoại khoa. Y học Việt nam. 316(11): 478 - 493.

5. Đỗ Kim Quế (2006) Nhiễm trùng ống ghép mạch máu: Chẩn đoán và điều trị. Y học Việt nam. 328: 239 - 246.

6. Đỗ Kim Quế, Nguyễn Anh Trung (2014) Tắc động mạch chủ chậu mạn tinh: chẩn đoán và điều trị phẫu thuật. Tạp chí Y học Thành phố Hồ Chí Minh. 18(3): 377 - 382.

7. Lê Đức Tín (2012), "Đánh giá kết quả phẫu thuật kết hợp can thiệp nội mạch trong điều trị tắc động mạch mạn tính chi dưới", Luận văn thạc sỹ Y Học, Đại học Y Dược Thành phố Hô Chí Minh.

8. Nguyễn Văn Trang (2014), "Vai trò của chỉ số $\mathrm{ABI}$ trong chẩn đoán và điều trị bệnh tắc động mạch mạn tính chi dưới", Luận văn thạc sỹ Y Học, Đại học Y Dược TP.Hồ Chí Minh.

9. Bandyk DF, Novotney ML, Johnson BL, Back MR, Roth SR. Use of rifampin-soaked gelatin-sealed polyester grafts for in situ treatment of primary aortic and vascular prosthetic infections. J Surg Res 2001; 95: 44-9. Brewter DC. (2005) Direct reconstruction for aortoiliac occlusive disease. In Vascular surgery $6^{\text {th }}$ Ed. Elservier Saunder Inc. p. $1106-1136$.

10. Brewter DC. (1991) Clinical and anatomic considerations for surgery in aortoiliac disease and results of the surgical treatment. Circulation 83(suppl I): I 42.

11. Carol D, Hons BA, Mc Collum C. Heparin-bonded dacron orpolytetraflouroethylene for femoro-popliteal bypass grafting: Amulticenter trial.J Vasc Surg2001; 33: 533-539.

12. Chiu KW, Davies RS, Nightingale PG, Bradbury AW, Adam DJ. Review of direct anatomical open surgical management of atherosclerotic aorto-iliac occlusive disease. Eur J Vasc Endovasc Surg 2010;39:460-71. Davidovic LB, Lotina SI, Kostic DM (1997). "Factors determining late patency of aortobifemoral bypass graft". Srp Arh Celok Lek, PubMed, 125 (1,2), pp 24-35.

13. Doty DB. Extra-anatomic aortic bypass for thoracic aortic obstruction. J Thorac Cardiovasc Surg 2001; 121: 1222-3.

14. Elkouri S Hudon G, Demers $P$ et al. (1999) Early and long term results of percutaneous transluminal angioplasty of the lower abdominal aorta. J Vasc Surg 30: 679.

15. Feliciano DV. Heroic procedures in vascular injury management: the role of extraanatomic bypasses. Surg Clin North Am 2002; 82: 115-24.

16. Hood DB, Hodgson KJ. (1999) Percutaneous transluminal angioplasty and stenting for iliac artery occlusive disease. Surg Clin North Am 79: 575. 
17. Horowitz JD, Durham JR. (1994) Surgical managenment of aortoiliac occlusive disease. In Vascular disease Interventional and surgical treatment. Churchill Livingstone Inc. p. $466-478$.

18. Huber KL, Joseph A, Mukherjee D. Extra-anatomic arterial reconstruction with ligation of common iliac arteries and embolization of the aneurysm for the treatment of abdominal aortic aneurysms in high-risk patients. J Vasc Surg 2001; 33: 745-51. Jovanović M,Jovanović J, Rančić Z, Stanojević G, Milić D, Stojanović M. (2005) Revascularization of highrik aortoilicac occlussion. Medicine and Biology. 12(1): $33-36$.

19. Madan AK, Santora TA, Disesa VJ. Extra-anatomic bypass grafting for aortoesophageal fistula: a logical operation. J Vasc Surg 2000; 32: 1030-3.

20. Massoun H., Gunther HJ., Hohner E., Storz LW. : Das akute Leriche syndrom. Angio 1990, 12(2) : 37-42.

21. Pai M, Handa A, Hands L, Collin J. (2003) Femoro-femoral arterial bypass is an effective and durable treatment for symptomatic unilateral iliac artery occlusion. Ann R Coll Surg Engl 85: 88-90.

22. Passman MA, Taylor LM Jr., Moneta GL, Edwards JM, Yeager RA, McConnellDB, Porter JM. (1998) Axillofemoral and aortofemoral bypass for aortoiliac, J Vasc Surg 23(2): 263-71.
23. Rholl KS, Breda A. (1994) Percutaneous intervention for Aortoiliac disease. In Vascular disease Interventional and surgical treatment. Churchill Livingstone Inc. p. $433-466$

24. Sarıkaya S, Aksoy E, Taşar M, Elibol A, Şişmanoğlu M, Fedakar A, Kırali K. (2013) Thoracic aortofemoral artery bypass: an alternative procedure for initialtreatment of critical aortoiliac occlusive disease. Türk Göğüs Kalp Damar Cerrahisi Dergisi 21(1):49-53.

25. Seeger JM, Pretus HA, Welborn MB, Ozaki CK, Flynn TC, Huber TS. Long-term outcome after treatment of aortic graft infection with staged extra-anatomic bypass grafting and aortic graft removal. J Vasc Surg 2000; 32: 451-9.

26. Tadahiro Sasajima T, Inaba M, Azuma N, Akasaka N, Asada H, Uchida H, Sasajima Y, Goh K. (2002) Novel anastomotic method enables aortofemoral bypass for patients with porcelain aorta.J Vasc Surg 35:1016-9.

27. Thaveau F, Dion YM, de Wailly GW, Dumont M, Laroche M. (2003) Early transient hydronephrosis after laparoscopicaortobifemoral bypass grafting.J Vasc Surg 38:603-608.

28. Ten Raa S, Van Sambeek MR, Hagenaars T, Van Urk H. Management of aortic graft infection. J Cardiovasc Surg (Torino) 2002; 43: 209-15. 